\title{
PENGARUH SUPLEMENTASI MULTI NUTRIENT BLOCK TERHADAP STATUS HEMATOLOGI KELINCI LOKAL
}

\author{
PUGER A.W., I M. NURIYASA, I M. MASTIKA DAN I M. SUASTA \\ Fakultas Peternakan Universitas Udayana, Denpasar Bali \\ e-mail: puger.anton@gmail.com
}

\begin{abstract}
ABSTRAK
Penelitian telah dilakukan untuk mengetahui status hematologi kelinci diberi pakan rumput yang disuplementasi Multi Nutrient Block (MNB). Rancangan yang digunakan adalah rancangan acak kelompok, dengan lima kali ulangan. Perlakuan terdiri dari kelinci diberi rumput lapangan sebagai kontrol (Ro), ransum kontrol yang disuplementasi MNB 5 g/ekor/h (R1), ransum kontrol yang disuplementasi MNB $10 \mathrm{~g} / \mathrm{ekor} / \mathrm{h}$ (R2), ransum kontrol yang disuplementasi MNB $15 \mathrm{~g} / \mathrm{ekor} / \mathrm{h}$ (R3). Hasil penelitian menunjukkan bahwa kandungan eritrosit, leukosit, hematokrit, glukosa dan trigiserida darah kelinci tidak dipengaruhi oleh tingkat suplementasi MNB $(\mathrm{P}<0,05)$, namun kandungan haemoglobin darah kelinci semakin meningkat dengan meningkatnya suplementasi MNB ( $>>0,05)$. Dapat disimpulkan bahwa suplementasi MNB berpengaruh positif terhadap status haemoglobin darah kelinci.
\end{abstract}

Kata kunci; MNB, status hematologi, Lepus negricollis

\section{EFFECT OF MULTI NUTRIENT BLOCK ON THE HEMATOLOGICAL STATUS OF LOCAL RABBIT}

\begin{abstract}
Research has been done to determine the hematological status of rabbits fed grass supplemented by Multi Nutrient Block (MNB). The design used was a randomized block design, with five replications. The treatment consisted of rabbits given field grass as control (Ro), control rations supplemented by MNB $5 \mathrm{~g} / \mathrm{head} / \mathrm{d}$ (R1), supplemented control rats MNB $10 \mathrm{~g} / \mathrm{head} / \mathrm{d}$ (R2), control rations supplemented MNB $15 \mathrm{~g} / \mathrm{head} / \mathrm{d}$ (R3). The results showed that the content of erythrocytes, leukocytes, hematocrits, glucoses and rabbit blood triglycerides were not influenced by the level of MNB supplementation ( $\mathrm{P}<0.05$ ), however, the content of hemoglobin increased with increasing supplementation of MNB (P> 0.05). It can be concluded that supplementation of MNB had positively effects on the status of hemoglobin in rabbit blood.
\end{abstract}

Keywords; MNB, haematological status, Lepus negricollis

\section{PENDAHULUAN}

Kelinci merupakan ternak kecil yang kalau dikembangkan dengan sungguh-sungguh mampu memberdayakan masyarakat kecil dan kurang mampu. Hal ini didukung oleh siklus kehidupan kelinci yang relative pendek untuk siap dipotong, cepat berkembang biak karena bersifat prolifik, pemeliharaannya mudah dan bahan makanan kelinci tidak terlalu sulit dan tidak mahal yaitu berupa rumput-rumputan. Modal usaha lebih kecil dan lahan yang diperlukan juga tidak seluas yang diperlukan ternak ruminansia. Schiere (1999) menyatakan bahwa pengembangan peternakan kelinci memberi peluang cukup besar dalam memenuhi kebutuhan gizi masyarakat. Dilihat dari potensi, kelinci merupakan ternak dwifungsi disamping sebagai hewan kesayangan atau hewan hias, juga sebagai ternak penghasil daging. Daging kelinci mengandung protein tinggi dan rendah kolesterol.

Dalam kehidupan sehari-hari, pemeliharaan kelinci masih sangat tradisional, kelinci hanya diberi makan rumput-rumputan atau sisa sisa sortiran sayuran. Peternak tidak pernah menghitung kebutuhan ternak dan belum ada upaya memberikan pakan konsentrat untuk memacu pertumbuhan. Kondisi ini sering merugikan peternak sendiri karena mortalitas menjadi tinggi sehingga petani kehilangan pendapatan dan wakttu. Akar persoalannya adalah pengetahuan tentang kualitas ransum sangat rendah terutama pemahaman protein, energi dan mineral (Suttle, 2010). Pemberian pakan seadanya, tidak pernah mempertimbangkan kualitas dan kuantitas 
Tabel 1 Komposisi dan kandungan Nutrisi Multi Nutrient Block (MNB)

\begin{tabular}{|c|c|c|c|c|c|c|c|}
\hline Bahan & $\%$ & $\mathrm{ME}(\mathrm{Kkal} / \mathrm{Kg})$ & $\mathrm{CP}(\%)$ & $\mathrm{Ca}(\%)$ & Pav (\%) & Lemak (\%) & CF (\%) \\
\hline Molases*) & 5 & 98 & & & & & \\
\hline Polar*) & 18 & 205,2 & 2,12 & 0,02 & 0,06 & 0.057 & 14.75 \\
\hline Ampas Tahu terfermentasi***) & 60 & 1698 & 14,17 & 0,32 & 0,14 & 6 & 0.6 \\
\hline Semen putih & 5 & 0 & 0 & 0 & 0 & 0 & 0 \\
\hline Kalsium Hidro Posfat**) & 6.5 & 0 & 0 & 1,66 & 1,17 & 0 & 0 \\
\hline $\mathrm{NaCl}$ & 0.5 & 0 & 0 & 0 & 0 & 0 & 0 \\
\hline Minyak kelapa*) & 5 & 430 & 0 & 0 & 0 & 0 & 0 \\
\hline Total & 100 & 2431,2 & 16,29 & 2,0 & 1,37 & 6.057 & 15.35 \\
\hline
\end{tabular}

pakan dan pemberian pakan yang sama pada semua status fisiologis. Ketersediaan nutrisi dalam kuantitas dan kualitas tidak cukup untuk memenuhi kebutuhan ternak sehingga tingkat kematian anak kelinci menjadi tinggi dan induk cenderung menjadi kanibalisme. Xiccato et al. (1999) menyatakan bahwa keseimbangan nutrien dalam ransum sangat menentukan produktivitas ternak kelinci. Menurut de Blass dan Wiseman (1998) protein, karbohidrat, lemak, mineral, vitamin dan air merupakan nutrien yang sangat diperlukan oleh ternak kelinci. Hasil penelitian Salma (2004) mendapatkan bahwa persentase kebuntingan kelinci yang diberi ransum dengan kandungan protein $21 \%$ lebih tinggi daripada $16,64 \%$ dan $13,17 \%$ masing-masing $100 \%, 60 \%$ dan $49 \%$.

Asupan pakan dengan kualitas dan kuantitas yang cukup akan cepat dicerna dan diserap dan didistribusikan oleh darah ke sel-sel di seluruh tubuh ternak yang salah satunya berfungsi pembentukan sel-sel darah agar ternak dapat bertahan hidup. Komponen darah tentu sangat dipengaruhi oleh kualitas dan kuantitas makanan yang diserap. Komponen darah sangat memengaruhi produktivitas dan kehidupan serta keharmonisan fungsi setiap organ ternak (Yupardhi, 2001). Hill et al. (2008) menyatakan bahwa dalam proses kehidupan reaksi biokimia tubuh memerlukan protein dan enzim sebagai katalisator sehingga membuat reaksi-reaksi biokimia dan penyerapan asupan pakan lebih cepat.

Berdasarkan perihal tersebut maka perlu dipelajari pengaruh pemberian suplementasi multi nutrient block terhadap status hematologi darah kelinci.

\section{MATERI DAN METODE}

\section{Kelinci}

Kelinci yang digunakan dalam penelitian ini adalah kelinci jantan lokal (Lepus nigricollis) dengan bobot badan awal 600,o $\pm 96,5$ gr. Bibit kelinci didatangkan dari desa Riang Gede Tabanan.

\section{Kandang}

Penelitian menggunakan 20 petak kandang battery dengan ukuran masing-masing panjang $70 \mathrm{~cm}$, lebar $50 \mathrm{~cm}$ dan tinggi $45 \mathrm{~cm}$ (Sceire, 1999). Ketinggian petak kandang diukur dari lantai bangunan kandang adalah 70 $\mathrm{cm}$. Masing-masing petak kandang dilengkapi dengan tempat makanan dan tempat air minum yang terbuat dari tempurung kelapa.

\section{Variabel yang Diamati}

Variabel hematologi yang diamati adalah kandungan hemoglobin (\%), jumlah sel merah (Eritrosit $10^{6} / \mu \mathrm{l}$ ), jumlah sel darah putih (Leukosit 103/ $\mu$ l), hematocrit (\%), glukosa (mg/10oml), dan trigliserida darah (mg/10oml), sesuai dengan metode Nugraha (2010). Pengamatan hanya sekali dilakukan diakhir penelitian setelah kelinci berumur 17 minggu. Pengambilan sampel darah dilakukan pada setiap blok dari perlakuan sehingga ada 20 sampel darah. Sampel darah diambil pada pagi hari sebelum kelinci diberi nakan dan minum. Cara pengambilan contoh darah dilakukan dengan menusukkan jarum pada vena telinga, kemudian disedot dengan spuit plastic dan segera dipindahkan ke dalam tabung reaksi yang telah diisi zat anti belu darah. Zat anti beku darah yang digunakan adalah lithium heparin (Xiangmei, 2008). Jumlah sampel darah yang diambil adalah sebanyak 6 cc untuk setiap ekor kelinci (Nugraha, 2010). Segera setelah itu dimasukan ke dalam termos es dan langsung dikirim ke Laboraatorium Kesehatan Masyarakat, Bina Medika, Denpasar untuk dianalisis hematologi. .

\section{Analisis Statistik}

Data yang diproleh dianalisis dengan analisis ragam, apabila diantara perlakuan terdapat perbedaan yang nyata $(\mathrm{P}<0,05)$ maka analisis dilanjutkan dengan uji jarak berganda Duncan (Steel dan Torrie, 1980).

\section{HASIL DAN PEMBAHASAN}

Hasil penelitian mendapatkan bahwa kelinci yang diberi perlakuan rumput lapangan saja (Ro) menyebabkan kandungan haemoglobin darah 12,54 g/100 ml (Tabel 2). Kelinci yang diberi rumput lapangan sebagai pakan dasar dengan suplementasi MNB $5 \mathrm{~g} / \mathrm{ekor} / \mathrm{hr}$ (R1) menyebabkan kandungan haemoglobin darah o,16\% lebih rendah tetapi tidak berbeda nyata $(\mathrm{P}>0,05)$ dibandingkan dengan Ro, sedangkan pemberian suplementasi 10 
g/ekor/hari (R2) dan $15 \mathrm{~g} /$ ekor/hari (R3), menyebabkan kandungan hemoglobin darah masing-masing 11,38\% dan $13,34 \%$ nyata lebih tinggi dari Ro $(\mathrm{P}<0,05)$. Respon hematologi kelinci yang diberikan suplementasi MNB semakin tinggi menghasilkan haemoglobin lebih tinggi, hal ini disebabkan karena pertumbuhan ternak kelinci R3 paling tinggi sehingga pembentukan organ-organ pertumbuhan termasuk haemoglobin darah juga tinggi. Puger et al. (2016) melaporkan bahwa pertumbuhan yang tinggi didukung oleh kecernaan pakan yang tinggi dan kecernaan tertinggi terjadi pada kelinci diberi suplementasi MNB pada tingkat $15 \mathrm{~g}$ /ekor/hari. Nuriyasa (2012) melaporkan bahwa konsumsi ransum dan tingkat pertumbuhan yang tinggi akibat dari retensi energi dan protein yang tinggi sehingga proses pembentukan haemoglobin darah lebih tinggi. Haemoglobin darah merupakan sarana transportasi oksigen dalam jaringan tubuh yang diperlukan dalam proses metabolisme. Hasil penelitian ini lebih tinggi dengan yang didapatkan Bivin dan King (1995) yaitu 12,80 mg/10oml, perbedaan ini mungkin disebabkan perlakuan yang diberikan berbeda.

Tabel 2. Status hematologi darah kelinci diberi suplementasi Multi Nutrient Block

\begin{tabular}{lrrrrr}
\hline \multirow{2}{*}{ Variabel } & \multicolumn{5}{c}{ Perlakuan } \\
\cline { 2 - 6 } & \multicolumn{1}{c}{ R0 } & \multicolumn{1}{c}{ R1 } & \multicolumn{1}{c}{ R2 } & \multicolumn{1}{c}{ R3 } & \multicolumn{1}{c}{ SEM } \\
\hline Haemoglobin $(\mathrm{g} / 100 \mathrm{ml})$ & $12,54^{\mathrm{b}}$ & $12,52^{\mathrm{b}}$ & $14,15^{\mathrm{a}}$ & $14,47^{\mathrm{a}}$ & 0,18 \\
Eritrosit $\left(10^{6} / \mu \mathrm{l}\right)$ & $3,64^{\mathrm{a}}$ & $4,07^{\mathrm{a}}$ & $4,48^{\mathrm{a}}$ & $4,78^{\mathrm{a}}$ & 0,18 \\
Leukosit $\left(10^{3} / \mu \mathrm{l}\right)$ & $5,44^{\mathrm{a}}$ & $6,12^{\mathrm{a}}$ & $6,18^{\mathrm{a}}$ & $6,95^{\mathrm{a}}$ & 0,34 \\
Hematokrit $(\%)$ & $38,97^{\mathrm{a}}$ & $40,18^{\mathrm{a}}$ & $42,72^{\mathrm{a}}$ & $42,43^{\mathrm{a}}$ & 1,35 \\
Glukosa $(\mathrm{mg} / 100 \mathrm{ml})$ & $163,51^{\mathrm{a}}$ & $157,25^{\mathrm{a}}$ & $170,72^{\mathrm{a}}$ & $188,5^{\mathrm{a}}$ & 20,41 \\
Trigliserida $(\mathrm{mg} / 100 \mathrm{ml})$ & $94,05^{\mathrm{a}}$ & $94,14^{\mathrm{a}}$ & $95,25^{\mathrm{a}}$ & $102,66^{\mathrm{a}}$ & 4,53 \\
\hline
\end{tabular}

1) RO : Ramsum rumput lapangan tanpa suplementasi MNB

R1 : Ransum rumput lapangan dengan suplementasi MNB $5 \mathrm{~g} / \mathrm{hr}$

$\mathrm{R} 2$ : Ransum rumput lapangan dengan suplementasi MNB $10 \mathrm{~g} / \mathrm{hr}$

R3 : Ransum rumput lapangan dengan suplementasi MNB $15 \mathrm{~g} / \mathrm{hr}$

2) Superskrip yang sama pada baris yang sama menunjukkan perbedaan tidak nyata $(P>0,05)$.

3) SEM : Standard Error of The Treatment Means.

Jumlah eritrosit darah kelinci yang mendapat per-

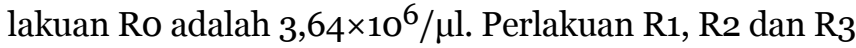
menyebabkan jumlah eritrosit masing-masing $10,57 \%$, $18,75 \%$ dan $23,85 \%(\mathrm{P}>0,05)$ lebih tinggi namun perbedaan ini tidak nyata. Terdapat kecenderungan meningkatnya jumlah eritrosit meski tidak nyata dengan kenaikan suplementasi MNB, hal ini disebabkan karena pertumbuhan kelinci $\mathrm{R}_{3}$ paling tinggi. Semakin tinggi pertumbuhan semakin banyak kandungan eritrosit dalam darah kelinci. Pertumbuhan yang tinggi memerlukan kandungan eritrosit darah yang tinggi sebagai transportasi oksigen dan zat-zat gizi lainnya yang diperlukan dalam proses metabolisme. Rata-rata kandungan eritrosit kelinci jantan lokal yang diberikan perlakuan ransum disuplementasi MNB $4,24 \times 10^{6} / \mu$, dan lebih tinggi sedikit dibandingkan dengan hasil penelitian Nuriyasa (2012) yang mendapatkan kandungan eritrosit kelinci

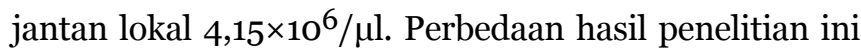
disebabkan oleh bahan penyusun ransum dan tingkat pertumbuhan masing-masing ternak. Menurut Bivin dan King (1995) kisaran normal jumlah eritrosit yaitu 4,0 $6,7 \times 106 / \mu \mathrm{l}$.

Jumlah leukosit kelinci diberi pakan rumput saja (Ro)

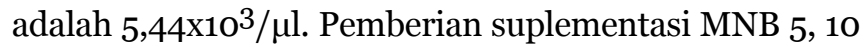
dan $15 \mathrm{~g} /$ ekor/hari tidak berpengaruh nyata $(\mathrm{P}>0,05)$ terhadap kandungan leukosit darah kelinci. Kandungan leukosit kelinci untuk R1, R2 dan $\mathrm{R}_{3}$ masing-masing $6,12 \times 10^{3} / \mu \mathrm{l}, 6,18 \times 10^{3} / \mu \mathrm{l}$ dan $6,95 \times 10^{3} / \mu \mathrm{l}$. Ini menunjukkan kelinci yang diberikan perlakuan ransum dengan suplementasi MNB tidak mengalami tingkatan stress berbeda sehingga kandungan leukosit dalam darah pada semua perlakuan tidak berbeda. Hasil ini sejalan dengan penelitian Nuriyasa (2012), Biving dan King (1995), masing-masing $\left(5,78-6,37 \times 10^{3} / \mu \mathrm{l}\right),\left(5,2-12 \times 10^{3} / \mu \mathrm{l}\right)$ dan $\left(6,3-10 \times 10^{3} / \mu \mathrm{l}\right)$. Harcourt (2002) mendapatkan jumlah leukosit normal pada kelinci $5^{-12} \times 10^{9 / 1}$ dan menurut Milas et al. (2009) pada kelinci New Zealand White 4,2$13,2 \times 10^{9 / 1}$.

Kelinci yang mendapat perlakuan ransum Ro menyebabkan kandungan hematokrit darah paling rendah 38,97\% namun tidak berbeda dengan R1, R2 dan R3 masing-masing 40,18\%, 42,72\% dan 42,43\%. Hasil penelitian ini mendapatkan kandungan hematokrit darah kelinci jantan lokal yang diberikan ransum $\mathrm{R}_{3}$ cenderung lebih tinggi dari perlakuan lainnya, hal ini disebabkan karena makin tinggi pertumbuhan maka proses pembentukan jaringan tubuh termasuk sel-sel darah juga meningkat. Rata-rata kandungan hematokrit darah kelinci yang diberikan ransum disuplementasi MNB adalah 41,082\% dan dalam kisaran yang sama dengan penelitian Nuriyasa (2012) yang mendapatkan kandungan hematokrit darah kelinci jantan lokal berkisar antara $39,5 \%-42,25 \%$.

Glukosa darah dan Trigliserida darah kelinci tidak berbeda nyata $(\mathrm{P}>0,05)$ diantara perlakuan ransum Ro, R1, R2 dan R3, seperti pada Tabel 2. Kandungan glukosa darah kelinci pada semua perlakuan tidak menunjukkan perbedaan yang nyata, hal ini menunjukan bahwa suplementasi MNB dalam ransum kelinci tidak berpengaruh terhadap mobilisasi glukosa dari simpanan glikogen atau pergantian sumber energi asal lemak (glukoneogenesis). Kandungan trigliserida darah kelinci yang diberikan perlakuan tidak berbeda dengan kontrol. Tidak berbedanya kandungan trigliserida karena konsumsi lemak dan kecukupan enersi dalam tubuh. Apabila konsumsi energi tidak mencukupi, ternak akan membongkar cadangan energi dalam bentuk trigliserida.Penggunaan ampas tahu dalam MNB mungkin juga berpengaruh. Hal ini sesuai dengan pendapat Trisnadewi et al. (2015) bahwa penggunaan 10-30\% ampas tahu terfermentasi oleh kultur S. cerevisiae dalam ransum menurunkan jumlah lemak ab- 
domen dan kadar serum kolesterol darah itik. Budaarsa (1997) melaporkan bahwa konsumsi serat kasar yang tinggi menyebabkan asam lemak atau kolesterol diikat oleh selulosa atau asam propionat sehingga dapat menghambat pembentukan kolesterol di hati. Fraksi serat kasar ternyata dapat berperan mengikat lemak dan garam empedu pada saluran pencernaan kelinci sehingga lemak yang dapat diserap ke dalam tubuh juga menurun (Sutardi, 1991). Bahkan suplementasi enzyme Phylazim 0,30\% dalam ransum menurunkan kadar kolesterol serum darah ayam petelur Lohman Brown umur 42-50 minggu (Witariadi et al., 2014)

\section{SIMPULAN}

Berdasarkan hasil penelitian diatas maka dapat disimpulkan bahwa suplementasi Multi Nutrient Block sampai 15g/ekor/hari dengan pakan dasar rumput lapangan meningkatkan kandungan haemoglobin darah kelinci Lepus negricollis.

\section{UCAPAN TERIMAKASIH}

Terimakasih disampaikan kepada Direktorat Penelitian dan Pengabdian Masyarakat Direktorat Jendral Pendidikan Tinggi Kementerian Pendidikan dan Kebudayaan melalui Rektor Universitas Udayana atas bantuan dana sehingga penelitian dapat terlaksana dan publikasi hasil penelitian ini dapat terwujud

\section{DAFTAR PUSTAKA}

Bivin, W.S. and W.W. King. 1995. Raising Healthy Rabbit. A Publication of Christian Veterinary Mission. Washington, USA

Budaarsa K. 1997. Kajian Penggunaan Rumput Laut dan Sekam Padi sebagai Sumber Serat dalam Ransum untuk Menurunkan Kadar Lemak Karkas dan Kolesterol Daging Babi. Disertasi. Institut pertanian Bogor. Bogor

De Blass, C and J. Wiseman. 1998. The Nutrition of the Rabbit. CABI Publishinr. University of Nottingham. Nottingham. P.39-55.

Duldjaman, M. 2005. Kualitas karkas domba yang diberi pakan rumput kering dan ditambah ampas tahu. J. Pengembangan Peternakan Tropis.

Harcourt B.F. 2002. Text Book of Rabbit Medicine. Butterworth-Heinemann. Linacre House, Jordan Hill, Oxford.

Hill R.W., G.A. Wyse, M. Anderson. 2008. Animal Physiology. $2^{\text {nd }}$ ed. Masschasusett Sinauer Ass., Inc. Pub. Sounderland

Milas N. P., K.S. Ika, V. Marijan, S.M.Terezija, B.P.Alenka, M. Zoran. 2009. Blood cell count analyses and erythrocyte morphometry in New Zealand White Rabbits. Veterinarski Arhiv 79(6) : 561-571.

Nugraha, K.A. 2010. Laboratorium Klinik: Pemeriksaan Darah (Blood Analysis). http://Komitekeperawatan- rsdsoreang.blogspot.com/2010/02/laboratoriumklinik-pemeriksaan-darah/html. Disitir Tanggal 12 Nopember 2010

Nuriyasa, M. 2012. Respon Biologi Serta Pendugaan Kebutuhan Energi dan Protein Ternak Kelinci Kondisi Lingkungan berbeda Di Daerah Dataran Rendah Tropis. Disertasi. Program Pasca Sarjana. Universitas Udayana. Denpasar.

Puger, A.W., I M. Nuriyasa, E. Puspany dan I M. Mastika. 2016. Kecernaan pakan kelinci local (Lepus negricollis) yang diberi pakan Multi Nutrient Block berbasis rumput lapangan. Majalah Ilmiah Peternakan Vo 19 No 3 Tahun 2016. Hal: 121-124

Salma, U., A.G. Miah, Y. Akter, Z.H. Khandaker and A.Reza. 2004. Effect of different of protein suplementation on reproductive performance of rabbit does under tropical condition. International Journal of Agriculture \&Biology.http://www.fspublishers.org/ijab/past-issues/IJAB vol.6 No.5/12. Disitir Tanggal 20 Nopember 2010.

Schiere, J.B. 1999. Backyard Farming in the Tropics. CTA Pubblished, New York.

Scott, M. L, Mc.Nesheim and R.J.Young.1982. Nutrition of Chicken. 3rd ed. MC.Scoff and Association. Ithaca. New York

Steel, R.G.D. and J.H. Torrie. 1980. Prinsip dan Prosedur Statistika. Suatu Pendekatan Biometrik. Edisi kedua. Diterjemahkan Oleh Sumantri. Gramedia. Jakarta.

Sutardi, T. 1991. Pemanfaatan limbah tanaman perkebunan sebagai pakan ternak ruminansia. Proseding Seminar Peningkatan Produksi dan Teknologi Peternakan. Fakultas Peternakan IPB dan Pemda Bogor. hal : 1-7

Suttle, N.F. 2010. Mineral Nutrition of Livestock. 4Ed. CABI. UK

Trisnadewi, A.A.A.S., I.G.N.G. Bidura, A.T. Umiarti dan A.W . Puger. 2015. Pemanfaatan ampas tahu terfermentasi dalam ransum untuk turunkan akumulasi lemak dan kolesterol tubuh itik. Majalah Ilmiah Peternakan. Vol 18 No 2 Tahun 2015 hal:55-60

Witariadi, N.M., N.G.K. Roni dan I.A. P. Utami. 2014. Penambahan enzim fitase kompleks dalam ransum berbasis dedak padi terhadap produksi kadar kolesterol telur ayam Lohman Brown. Majalah Ilmiah Peternakan. Vol 17 No 3 Tahun 2014. Hal 107-112.

Xiangmei, G. 2008. Rabbit Feed Nutrition Study for Intensive, Large-Scale Meat Rabbit Breeding. Qingdao Kangda Food Company Limited, China. http://www.mekarn. org/prorab/guan.htm. Disitir Tanggal 18 Nopember 2010.

Xiccato, G. M.Bernardini, C.Castellini, A. Dalle Zotte, P.I. Queaque and A.Trocino.1999. Effect of postweaning feeding on the performance and energy balance of famale rabbits at different physiological states. Journal of Animal Science, Vol. 77 (2) : 416-426. http://jas.fas org/cgi/content/abstract/77/2/416. Disitir Tanggal 20 Nopember 201.

Yupardhi W.S., R.B. Matram, W. Wirtha. 2001. Fisiologi Hewan. Buku Ajar. Denpasar. UPT Penerbit Universitas Udayana. 